\title{
DIE LEWENSVATBAARHEID VAN BOERBOKBOERDERY: 'N VERGELYKENDE GEVALLESTUDIE
}

\author{
Wilbrie Fourie* \\ North West University \\ Wilbrie@gmail.com \\ Merwe Oberholzer" \\ Pieter Buys+ \\ North West University \\ North West University \\ Merwe.oberholzer@nwu.ac.za. \\ Pieter.buys@nwu.ac.za
}

Received: October 2013

Accepted: June 2014

\begin{abstract}
The aim of this study was to design a case study where a number of management accounting evaluation techniques, namely performance measurement (short-term focus), capital investment evaluation (long-term focus) and risk, have been identified to compare the financial results of different scenarios between Boer goat, mutton breeds and beef cattle farming. The contribution of the study is that it simplifies the decision-making regarding the choice between the types of red meat farming used for different scenarios, namely farm size and available capital. Compliant software that have been developed, allow the user to compile unique scenarios and make decisions according to that. The value of this should be determined by taking into account that there are, as for other livestock types in South Africa, no readily available market indicators for the Boer goat currently. This deficiency leads to price uncertainty that makes it difficult to determine the value of the Boer goat industry.
\end{abstract}

Keywords

Boer goat; capital investment evaluation; performance measurement; risk; viability

*Mr WAS Fourie is a postgraduate student in the School of Accounting, North West University, Potchefstroom, South Africa.

\#Prof M Oberholzer, is a professor in the School of Accounting, North West University, Potchefstroom, South Africa.

+Prof PW Buys is a professor in the School of Accounting, North West University, Potchefstroom, South Africa. 


\section{INLEIDING}

Die fokus van hierdie studie is op die Suid-Afrikaanse boerbok as vleisproduk. Die S.A. Boerbok-, S.A. Savanna- en die S.A. Kalahari Redspesies is inheems aan Afrika, veredel in Suid-Afrika en staan onder die oorhoofse naam van "S.A. Boerbok" bekend (SA Boerboktelersvereniging, 2011). Die belangrikheid van die studie is dat die lewensvatbaarheid van dié spesie met ander rooivleisboerderye (beeste en skape) vergelyk word ten einde te bepaal of boerbokboerdery ' $n$ bydrae tot doeltreffender voedselproduksie kan lewer. Hierdie studie is deel van ' $n$ groter geheel waar ' $n$ gevallestudie ontwikkel is om die lewensvatbaarheid van boerbokboerdery te ondersoek. Twee verdere studies gebruik hierdie gevallestudie-inligting, naamlik om eerstens ' $n$ model te ontwikkel vir die kapitaalbehoeftes van boerbokboerdery, en om tweedens ' $n$ vergelykende studie te doen met betrekking tot die tegniese en skaaldoeltreffendheid van rooivleisproduksie in Suid-Afrika.

Verskillende fasette van boerbokboerdery is oor die jare al nagevors, byvoorbeeld Sheridan, Ferreira en Hoffman (2003) het die dieet en voedingsbenodigdhede van boerbokke ondersoek. Omphile, Aganga, Thsireletso en Nkele (2004), Du Plessis, Van der Waal en Webb (2004), Ferreira (2004), Malan (2000), Hashick en Kerley (1997) en Mason (1988) het fisiese eienskappe en dieetgewoontes van boerbokke ondersoek en met dié van ander spesies vergelyk. Gadiyaram en Kannan (2004) het die gehalte van boerbokvleis met dié van ander vleissoorte vergelyk. Die gesondheidseienskappe van boerbokvleis is deur Casey (1992) nagevors. Gouws (2002), Malan (2000) en Botha (1999) het die vraag na en bemarkbaarheid van boerbokvleis ondersoek. Lochner (2002) het die vrugbaarheid van boerbokke ondersoek, terwyl hul groot fisiese voorkoms deur De Waal (2006) ondersoek is. Die vorige navorsing toon dat daar reeds baie inligting oor die fisiese aspekte en bemarkbaarheid van die boerbokbedryf bestaan, maar min oor die finansiële lewensvatbaarheid van die bedryf. Hierdie studie vul hierdie leemte deur die navorsingsvraag te stel of dit finansieel lewensvatbaarder is om met boerbokke te boer in vergelyking met ander rooivleisproduserende spesies. Slegs enkele studies is in ' $n$ mate hieraan verwant, byvoorbeeld Casey en Van Niekerk (1988) het bevind dat die aanpasbaarheid van enige plaasdier ten opsigte van die klimaat en verskillende produksietegnieke een van die belangrikste ekonomiese karaktereienskappe vir verhoogde produksie en opbrengs op belegging van die boerdery is. Midgley (2007) het bepaal dat die vernaamste winsbepaler van vleisboerdery in die produksievolume opgesluit is.

Die doel van hierdie navorsing is om die lewensvatbaarheid van boerbokboerdery te ondersoek. $0 \mathrm{~m}$ die navorsing in perspektief te stel, sluit die doel in om 'n gevallestudie te ontwikkel met verskillende scenario's om die lewensvatbaarheid van boerbokboerdery, in vergelyking met ander rooivleisboerderye (bees en skaap), in Suid-Afrika te ondersoek. Daarom is ' $n$ aantal bestuursrekeningkundige evalueringstegnieke geïdentifiseer om vir verskillende scenario's die prestasiemeting (korttermynfokus), kapitaalinvesteringsevaluering (langtermynfokus) en risiko van boerbokboerdery met vleisskaap - en -beesboerderye te vergelyk.

Volgens Malan (2000:167) en Botha (1999:10) leen boerbokke hulself tot dubbelboerdery, waar boerbokke en ander spesies soos beeste saam kan wei sonder dat hulle direkte kompetisie vir mekaar is. 'n Beperking van hierdie studie is egter dat die prestasie, kapitaalinvestering en risiko slegs op 'n enkele spesie bereken word wat dubbelboerdery nie in ag neem nie. Nietemin, die bydrae van die studie is dat dit die besluitneming rakende die keuse tussen die tipe rooivleisbedryf vir verskillende scenario's, naamlik plaas- (of weidingsgrootte) en beskikbare kapitaal, vergemaklik. Meegaande sagteware wat ontwikkel is vir berekeninge in hierdie studie 
word beskikbaar gestel en gee die gebruiker daarvan die geleentheid om unieke scenario's op te stel en daarvolgens besluite te neem. Die waarde hiervan moet in die lig gesien word dat daar, soos vir ander vee-tipes in Suid-Afrika, tans geen geredelik beskikbare markaanwysers vir boerbokke bestaan nie. Tans word slegs daaglikse markaanwysers, soos vleispryse, van verskillende graderings (byvoorbeeld $A, A B, B$ en $C$ ) bees, skaap, vark en hoender, en pryse van huide van beeste en skape, beskikbaar gestel (Landbouweekblad, 2013). Hierdie gebrek aan markaanwysers lei tot prysonsekerheid wat dit moeilik maak om die waarde van boerbokboerderye te bepaal.

Die res van die studie is soos volg georganiseer: Afdeling 2 verskaf die teorie rakende die bestuursrekeningkundige evalueringstegnieke. Die metode en ontwerp van die gevallestudie word in Afdeling 3 verduidelik. Afdeling 4 toon die resultate van die evalueringstegnieke vir die verskillende scenario's en gevolgtrekkings word in Afdeling 5 afgelei. Die studie word met ' $n$ samevatting en praktiese implikasies in Afdeling 6 afgesluit. In die res van die studie word die terme bokke, skape en beeste gebruik. Dit verwys, tensy anders aangedui, spesifiek na boerbokke, vleisskape en vleisbeeste.

\section{TEORIE}

Boerderybestuurders behoort nie slegs die fisiese en tegniese aspekte van die bedryf goed te ken nie, maar ook die ekonomiese en finansiële aspekte (Nell \& Napier, 2005:383-388). Daarom word hierdie gedeelte bespreek wat ' $n$ aantal bestuursrekeningkundige evalueringstegnieke identifiseer om die prestasie, kapitaalinvesteringsevaluering en risiko van boerbokboerdery met skaap- en beesboerderye te vergelyk.

Volgens Hawawini en Viallet (2011:250) is relevante kontantvloei slegs die verandering in die algehele kontantposisie wat aan die investeringsbesluit toegeskryf kan word. Die verskillende rooivleisboerderye het baie uitgawes wat soortgelyk is, byvoorbeeld grond-, selfoon- en voertuiguitgawes wat dus nie in berekening gebring word nie, aangesien dit nie deur die tipe boerderybedryf bepaal word nie. ' $n$ Bydraestaat wat slegs die relevante inkomste en uitgawes in ag neem, is gebruik om die bydraes van die verskillende rooivleisboerderye te bereken vir die doel van die gevallestudie. Die rede hiervoor is dat die verskil in die onderskeie boerderye uitgewys moet word. Die relevante bydrae is die verskil tussen die relevante inkomste, verkoopsinkomste van speen- en uitskotdiere, en relevante uitgawes, soos doserings, minerale byvoeding en arbeid. Aangesien dit ook as ' $n$ beleggingsbesluit beskou word, met opbrengs wat oor ' $n$ redelike tyd verkry kan word, sal die resultate vir' $n$ tydperk van vyf jaar bereken word.

\subsection{Prestasiemeting}

Die volgende prestasiemetingstegnieke is geselekteer om die korttermyn-finansiële prestasie van die drie spesies te bepaal. Opbrengs op investering, bruto wins (bydrae) persentasie en bydrae per hektaar is winsgewendheidsverhoudings en bate-omset ' $n$ batebestuursverhouding (Lovemore \& Brümmer, 2005:x).

- Opbrengs op investering: Die vergelyking vir hierdie berekening is die bedryfswins gedeel deur kapitaal geïnvesteer om winsgewendheid met betrekking tot totale bates aangewend, te meet (Correia, Flynn, Uliana \& Wormald, 2010:5-18; Hawawini \& Viallet, 2011:628). Vir hierdie studie is die bedryfswins met die relevante bydrae vervang. Kapitaal geïnvesteer bestaan uit die aankoopkoste van die kudde en relevante kapitale uitgawes soos voerbakke, omheining 
en veehanteringsgeriewe. Die totale relevante bydrae oor vyf jaar sal gedeel word deur die kapitaal aanvanklik aangewend.

- Bruto wins (bydrae) persentasie: Dit word bereken deur die bruto wins as 'n persentasie van die verkope uit te druk. Dit toon die verhouding van verkope wat behoue bly nadat uitgawes gedek is (Correia et al., 2010:5-17; Lovemore \& Brümmer, 2005:100). Die bruto wins is vir hierdie studie deur die relevante bydrae vervang (en word voortaan dus die bydraepersentasie genoem) en die verkope is alle relevante verkoopsinkomste met inagneming dat die dieselfde teelkuddegrootte gehandhaaf word. Die gemiddelde bydraepersentasie oor vyf jaar is in die berekeninge gebruik.

- Bate-omset: Dit word bereken deur die omset van 'n entiteit deur die totale bates daarvan te deel om benutting van die bates met betrekking tot omset te toon (Hawawini \& Viallet, 2011:616; Correia et al., 2010:5-15). Die totale bates is met die kapitaal geïnvesteer (soos hierbo omskryf is) vervang en omset is dieselfde as verkoopsinkomste hierbo. Die totale relevante inkomste oor vyf jaar is gedeel deur die aanvanklike kapitaal aangewend.

- Bydrae per hektaar: Die doel van hierdie verhouding is om die uitset wat ' $n$ boer vanaf die grondinset kry, te bereken deur die relevante bydrae deur die plaasgrootte te deel. Dit is dus die winsgewendheid met betrekking tot die plaasgrootte. Die totale bydrae per hektaar oor vyf jaar is bereken.

\subsection{Kapitaalinvesteringsevaluering}

Die volgende kapitaalinvesteringsevalueringstegnieke is geselekteer om die langtermynfinansiële prestasie van die drie spesies te bepaal (Correia et al., 2010:8-3):

- Terugbetaalperiode: Die oorspronklike vergelyking vir die berekening van die terugbetaalperiode is kapitaalinvestering gedeel deur jaarlikse kontantvloei (Correia et al., 2010:8-10), waar laasgenoemde met die jaarlikse relevante bydrae vervang word.

- Rekeningkundige opbrengskoers: Die rekeningkundige opbrengskoers word bereken deur gemiddelde jaarlikse wins deur die gemiddelde investering (begin en einde van projek) te deel (Hawawini \& Viallet, 2011:628). Vir die doel van die studie is die wins deur die relevante bydrae vervang. Die totale relevante bydrae oor vyf jaar is gedeel deur die gemiddelde kapitaal aangewend.

- Netto huidige waarde: Die netto huidige waarde is bereken deur die jaarlikse relevante bydrae en kapitaalinvesterings oor ' $n$ aantal jare tot die huidige waarde te verdiskonteer. Dit is bereken oor ' $n$ tydperk van vyf jaar en die koers wat gebruik is, is ' $n$ inflasiekoers van vier persent in ' $n$ relatiewe lae inflasietydperk plus ses persent opbrengs, as wyd aanvaarbare norm (Correia et al., 2010:7-24).

\subsection{Risiko}

Twee tegnieke om risiko te meet, is geïdentifiseer, naamlik:

- Sensitiwiteit: Die sensitiwiteitsanalise meet hoe ' $n$ projek se uitkomste sal verander indien enige van die invoerveranderlikes verander word (Correia et al., 2010:10-12). Vir die doel van hierdie studie is die verkoopsinkomste met een persent afwaarts gewysig om die verandering in relevante bydrae te meet. 
- Gelykbreekpunt: Volgens Correia et al. (2010:10-15) is die gelykbreekpunt van 'n projek die aantal eenhede wat ' $n$ projek moet verkoop om nul netto huidige waarde te lewer. In hierdie studie sal bepaal word met hoeveel persent die totale inkomste oor vyf jaar kan daal om ' $n$ relevante bydrae van nul te lewer.

\section{METODE EN ONTWERP VAN GEVALLESTUDIE}

'n Gevallestudie (met nege verskillende scenario's) is as metode vir hierdie studie gekies, aangesien dit gebruik word indien die eiesoortigheid en die kompleksiteit van 'n saak in sekere omstandighede verstaan wil word (Stake, 1995:6). Flyvbjerg (2006:228) noem dat 'n gevallestudie die kern van wetenskapsontwikkeling is en benadruk dat die krag van 'n voorbeeld nie onderskat moet word nie, aangesien daar maklik op grond van 'n enkele voorval veralgemeen kan word. 'n Gevallestudie is veelsydig deurdat dit geskik vir die generering en toetsing van hipoteses is en nie net tot die spesifieke funksies beperk is nie (Flyvbjerg, 2006:219). Die studie het hoofsaaklik 'n kwalitatiewe aanslag, waar onderhoude met sewe kundige persone gevoer is. Dit sluit in vier boerbokboere, 'n kenner van elk, veedosering, veehantering en plaasomheining.

In hierdie ondersoek is 'n gevallestudie gebruik om vir verskillende scenario's finansiële vergelykings te tref. In Scenario's 1, 2 en 3 word 'n plaasgrootte van 200 hektaar en kapitaal beskikbaar van R200 000, R500 000 en R900 000, respektiewelik, veronderstel. Scenario's 4, 5 en 6 veronderstel 'n plaasgrootte van 500 hektaar met dieselfde as bogenoemde kapitaalbedrae beskikbaar, respektiewelik, en Scenario's 7, 8 en 9 veronderstel 'n plaasgrootte van 900 hektaar met dieselfde as bogenoemde kapitaalbedrae beskikbaar, respektiewelik. Die res van hierdie afdeling verduidelik die ontwerp van die gevallestudie. Na aanleiding van gesprekke met die kundige persone het die outeurs bogenoemde verskillende plaasgroottes gekies om klein, medium en groot plase te verteenwoordig. Die drie beskikbare kapitaalbedrae is ook slegs 'n skatting van die outeurs om variëteit in die data te verkry.

Met boerbok- en skaapboerdery is die aanname dat die bokke en skape in die veld wei en in die aande in 'n klein kampie slaap. In die lamseisoen word die ooie in 'n lamkampie geplaas. Die beesboerdery veronderstel dat die beeste in die veld wei en slaap. Daar is ' $n$ aantal tegniese faktore wat die finansiële evaluering van die verskillende boerderytipes beïnvloed. $0 \mathrm{~m}$ die studie uit te voer, is aannames gemaak en word dit vervolgens bespreek.

- Plaasligging: Die plaas is in die Noordwes Provinsie in die Potchefstroom-omgewing geleë. In die Noordwes Provinsie is veeboerdery algemeen en dit is die provinsie in Suid-Afrika wat die vierde meeste vee het. Daar is in hierdie omgewing voldoende ondersteuning vir veeboerdery, soos byvoorbeeld markte, veilings, veekundiges, doseringsmiddels en veehanteringsgeriewe (Statistics South Africa, 2006).

- Veldsoort: Dit bestaan hoofsaaklik uit grasvlaktes met karooagtige bossies wat verspreid voorkom en word as Cymbopogon-Themeda veld beskryf (Acocks, 1988:37).

- Plaasgrootte: Dit is die area waarop aktief met die diere geboer word (weidingsarea) en die verskillende scenario's is 200, 500 en 900 hektaar en vir berekeningsdoeleindes word aanvaar dat die plase almal 'n perfekte vierkantige vorm het.

- Omheining: Die koste van die omheining sal slegs die fisiese benodighede insluit en nie arbeid nie. Aanvaar dat die area reeds omhein is met ' $n$ heining wat uit vyf gespande drade bestaan. Die aanbevole aantal drade vir die betrokke spesies is soos volg: Beeste vyf lyne, 
skape ses lyne en bokke tien lyne (Naude, 2011). Die kapitaal benodig vir omheining is dus slegs op skape en bokke van toepassing. Die koste van enkeldoringdraad beloop R0.56 per meter (Naude, 2011).

- Kudde-diversiteit: Aanvaar dat die kudde uit vroulike diere bestaan wat almal reeds gereed is om beset te word en ook binne een maand vanaf die begin van die studie beset sal word. Vir die doel van die studie sal aanvaar word dat daar genoegsame manlike teeldiere is, maar dat hulle getalle weglaatbaar klein is.

- Kuddegroei: Aanvaar dat die diere in die kudde se ouderdomme eweredig versprei is vanaf die ouderdom gereed om te produseer tot en met uitskot. Aanvaar dat uitskotdiere elke jaar verkoop word. Die teelkuddegrootte word deur aanteling aangevul. Die spesies van toepassing kan voorplant in die volgende ouderdomme: Beeste twee tot agt jaar, skape een tot agt jaar en bokke een tot tien jaar. Die volgende persentasies is van toepassing in die berekening van hoeveel persent van die kudde elke jaar as uitskot verkoop sal word: Beeste 14 persent, skape 17 persent en bokke 11 persent (Mouton, 2011; Van Zyl, B., 2011; Van Zyl, A., 2011).

- Aanteelpersentasie per jaar: Beeste 76 persent, skape 98 persent (Mouton, 2011; Van Zyl, B., 2011) en bokke 120 persent (Van Zyl, A., 2011; Boshoff, 2011).

- Verkooppryse: Die verkooppryse is vir beeste en skape soos gepubliseer in die Landbouweekblad (2011:1): Speenkalwers R17.80 per kilogram (op die hoef), uitskotbeeste R26.14 per kilogram, skaaplammers R20.83 per kilogram (op die hoef) en uitskotskape R44.13 per kilogram. Aangesien daar geen formele markaanwyser vir die prys van boerbokke is nie, is die mening van kenners gebruik (Van Zyl, A., 2011; Boshoff, 2011): Bokkapaters R26 per kilogram (op die hoef) en uitskotbokke R32 per kilogram.

- Aankoopprys: Die aankoopprys van vroulike diere is soos volg (Mouton, 2011; Van Zyl, B., 2011; Van Zyl, A., 2011; Boshoff, 2011): Beeste R7 125 per eenheid, skape R1 045 per eenheid en bokke Rl 500 per eenheid.

- Gewig: Die speen- en uitskotgewig van die beeste en skape is bepaal in oorleg met Mouton (2011) en Van Zyl, B. (2011): Beeste: Speengewig (op die hoef) 235 kilogram en uitskotgewig (karkas) 250 kilogram. Skape: Speengewig (op die hoef) 30 kilogram en uitskotgewig (karkas) 28,75 kilogram. Volgens Van Zyl, A. (2011) en Boshoff (2011) is die besonderhede met betrekking tot bokke soos volg: Speengewig (op die hoef) 30 kilogram en uitskotgewig (karkas) 23 kilogram.

- Drakrag: Die drakrag in hierdie gebied is soos volg (Mouton, 2011; Van Zyl, B., 2011; Van Zyl, A., 2011; Boshoff, 2011): Beeste vyf hektaar per eenheid, skape een hektaar per eenheid en bokke 0,86 hektaar per eenheid.

- Arbeid: Alhoewel die arbeidsintensiteit van die verskillende boerdery verskil, is daar nie ' $n$ konstante hoeveelheid arbeid vir elk boerdery nie, aangesien boere se siening van arbeidsbehoeftes verskil. Vir doeleindes van die studie is die volgende bedrae per eenheid per jaar gebruik: Beeste R168, skape R57,60 en bokke R57,60 (Mouton, 2011; Van Zyl, B., 2011).

- Kapitaal: Die kapitaal beskikbaar is voldoende om die plaas in te rig vir die aanhouding en hantering van die diere, sowel as die aankoop van die aanvanklike kudde. 
- Veehanteringsgeriewe: Aangesien daar verskeie faktore is wat ' $n$ rol speel by die oprigting van veehanteringsgeriewe (byvoorbeeld drukgange), is daar besluit om die gemiddelde bedrag vir die drie kuddegroottes (plaasgroottes) deur die bank te gebruik: Beeste R54 800, skape R33 947 en bokke R37 937 (De Chalain, 2010).

- Dosering: Dosering vir die verskillende boerderye in die gebied is aan die hand van Cilliers (2011) gedoen in oorleg met die bestuursprogram van SENWES-Potchefstroom. ' $n$ Lys van doseermiddels en doseringsperiodes is opgestel en die koste per vroulike teeldier is daarvolgens bereken: Beeste R215,61, skape R76,17 en bokke R70,55.

- Minerale byvoeding per jaar: Beeste R356,00, skape R163,11 en bokke R163,11 (Mouton, 2011; Van Zyl, B., 2011).

\section{BEVINDINGE}

Om die doel van die studie, die lewensvatbaarheid van boerbokboerdery met betrekking tot bees en skaapboerdery, te bereik, is vir die ontleding van elkeen van die nege scenario's, ' $n$ tabel opgestel wat al die waardes van die verskillende spesies ten opsigte van prestasiemeting, kapitaalinvesteringsevaluering en risikometing aandui. Alle berekeninge is volgens die Microsoft Excel program gedoen wat spesiaal vir die studie ontwikkel is. As gevolg van 'n spasiebeperking word die resultate van Scenario 1, plaasgrootte 200 hektaar en R200 000 beskikbare kapitaal, as voorbeeld gebruik, waarna slegs 'n opsomming van al die ander scenario's getoon sal word.

\subsection{Scenario 1 (200 hektaar en R200 000 kapitaal)}

TABEL 1: Resultate van evalueringstegnieke, 200 hektaar en R200 000

\begin{tabular}{lccc}
\hline Evalueringstegniek & Beeste & Skape & Bokke \\
\hline Prestasiemeting & & & \\
Opbrengs op investering & $104 \%$ & $188 \%$ & $243 \%$ \\
Bydraepersentasie & $70 \%$ & $56 \%$ & $60 \%$ \\
Bate-omsetsnelheid & $148 \%$ & $330 \%$ & $378 \%$ \\
Bydrae per hektaar & $\mathrm{R} 1044$ & $\mathrm{R} 1878$ & $\mathrm{R} 2430$ \\
Relevante bydrae & $\mathrm{R} 208736$ & $\mathrm{R} 375658$ & $\mathrm{R} 486087$ \\
Kapitaalinvesteringsevaluering & & & \\
Terugbetaalperiode & 4,84 jaar & $2,92 \mathrm{jaar}$ & $3.08 \mathrm{jaar}$ \\
Rekeningkundige opbrengskoers & $209 \%$ & $376 \%$ & $486 \%$ \\
Netto huidige waarde & $(\mathrm{R} 41 \mathrm{1400)}$ & $\mathrm{R} 70757$ & $\mathrm{R} 129464$ \\
Risiko & & & \\
Gelykbreekpunt & $70 \%$ & $57 \%$ & $64 \%$ \\
Sensitiwiteit & $1,42 \%$ & 1,76 & $1,55 \%$ \\
\hline
\end{tabular}

Bron: Empiriese bevindings

Die waardes in TABEL 1 is verwerk en as nieparametriese (rangorde) en parametriese (werklike waardes) skattings in TABEL 2 uitgedruk. Die nieparametriese verwerkings is sodanig dat ' $n$ 
rangorde van 1, 2 en 3 gebruik is, waar 3 die beste presteerder aandui. Die doel hiervan is om die data volgens grootte te orden (Steyn, Smit, Du Toit \& Strasheim, 1999:583). Met die parametriese vergelyking is die beste presteerder met $l$ aangedui en die ander twee is met betrekking tot die beste presteerder bereken.

TABEL 2: Scenario 1 (200 hektaar en R200 000 kapitaal): Nieparametriese en parametriese vergelyking

\begin{tabular}{|c|c|c|c|c|c|c|}
\hline \multirow[b]{2}{*}{ Evalueringstegniek } & \multicolumn{3}{|c|}{ Nieparametries } & \multicolumn{3}{|c|}{ Parametries } \\
\hline & Beeste & Skape & Bokke & Beeste & Skape & Bokke \\
\hline \multicolumn{7}{|l|}{ Prestasiemeting } \\
\hline Opbrengs op investering & 1 & 2 & 3 & 0,43 & 0,77 & 1,00 \\
\hline Bydraepersentasie & 3 & 1 & 2 & 1,00 & 0,80 & 0,85 \\
\hline Bate-omsetsnelheid & 1 & 2 & 3 & 0,39 & 0,87 & 1,00 \\
\hline Bydrae per hektaar & 1 & 2 & 3 & 0,43 & 0,77 & 1,00 \\
\hline Relevante bydrae & 1 & 2 & 3 & 0,43 & 0,77 & 1,00 \\
\hline Subtotaal & 7 & 9 & 14 & 2,68 & 3,98 & 4,85 \\
\hline \multicolumn{7}{|c|}{ Kapitaalinvesteringsevaluering } \\
\hline Terugbetaalperiode & 1 & 3 & 2 & 0,59 & 1,00 & 0,95 \\
\hline Rekeningkundige opbrengs & 1 & 2 & 3 & 0,43 & 0,77 & 1,00 \\
\hline Netto huidige waarde & 1 & 2 & 3 & $-0,32$ & 0,55 & 1,00 \\
\hline Subtotaal & 3 & 7 & 8 & 0,70 & 2,32 & 2,95 \\
\hline \multicolumn{7}{|l|}{ Risiko } \\
\hline Gelykbreekpunt & 3 & 1 & 2 & 1,00 & 0,81 & 0,91 \\
\hline Sensitiwiteit & 3 & 1 & 2 & 1,00 & 0,77 & 0,91 \\
\hline Subtotaal & 6 & 2 & 4 & 2,00 & 1,58 & 1,82 \\
\hline
\end{tabular}

Bron: Empiriese bevindings

Prestasiemeting: TABEL 2 toon dat bokke in vier van die vyf parameters die hoogste telling het. Volgens die subtotaal vir beide die nieparametriese en parametriese skattings het bokke die hoogste telling, gevolg deur skape en met beeste derde. Beeste se bydraepersentasie is die hoogste, met bokke tweede. Alhoewel relevante bydrae en bydrae per hektaar dieselfde persentasieverhouding weergee, is dit belangrik om beide aan te toon, aangesien relevante bydrae sal meebring dat akkurate kontantvloeibesluite geneem kan word.

Kapitaalinvesteringsevaluering: Volgens TABEL 2 is die skape se terugbetaalperiode die kortste, gevolg deur bokke en, heelwat swakker, gevolg deur beeste. Beide die rekeningkundige opbrengskoers en die netto huidige waarde van bokke is die hoogste. Die beeste se netto huidige waarde is negatief en is dus nie 'n goeie beleggingsgeleentheid nie. Die subtotale van die nieparametriese en parametriese skattings dui die hoogste telling vir bokke aan, gevolg deur skape en, heelwat swakker, gevolg deur beeste. 
Risiko: Die beeste is die mins riskante spesie, soos gemeet deur beide die gelykbreekpunt en sensitiwiteitsanalise. Bokke is in die tweede plek, gevolg deur skape.

\subsection{Opsomming van resultate: Scenario 1 tot Scenario 9}

\subsubsection{Gemiddelde telling volgens evalueringstegniek}

TABEL 3: Opsomming van resultate van Scenario 1 tot Scenario 9: Gemiddeldes per evalueringstegniek

\begin{tabular}{lcccccc}
\hline Scenario l tot 9 & \multicolumn{3}{c}{ Nieparametries } & \multicolumn{3}{c}{ Parametries } \\
& Beeste & Skape & Bokke & Beeste & Skape & Bokke \\
\hline Prestasiemeting & & & & & & \\
Opbrengs op investering & 1 & 2 & 3 & 0,62 & 0,85 & 0,99 \\
Bydraepersentasie & 3 & 1 & 2 & 1,00 & 0,73 & 0,83 \\
Bate-omsetsnelheid & 1 & 3 & 3 & 0,50 & 0,94 & 0,94 \\
Bydrae per hektaar & 1 & 2 & 3 & 0,58 & 0,74 & 0,99 \\
Relevante bydrae & 1 & 2 & 3 & 0,58 & 0,74 & 0,99 \\
Subtotaal & 7 & 10 & 14 & 3,28 & 4,00 & 4,74 \\
Kapitaalinvesteringsevaluering & & & & & & \\
Terugbetaalperiode & 1 & 2 & 3 & 0,62 & 0,95 & 0,96 \\
Rekeningkundige opbrengskoers & 1 & 2 & 3 & 0,62 & 0,85 & 0,99 \\
Netto huidige waarde & 1 & 2 & 3 & $-0,14$ & 0,59 & 0,88 \\
Subtotaal & 3 & 6 & 9 & 1,10 & 2,39 & 2,83 \\
\hline Risiko & & & & & & \\
Gelykbreekpunt & 3 & 1 & 2 & 1,00 & 0,74 & 0,86 \\
Sensitiwiteit & 3 & 1 & 2 & 1,00 & 0,64 & 0,83 \\
Subtotaal & 6 & 2 & 4 & 2,00 & 1,38 & 1,69 \\
\hline Bron:Empiriesebeindings & & & & & & \\
\hline
\end{tabular}

Bron: Empiriese bevindings

TABEL 3 is saamgestel uit die inligting soos vervat in TABEL 2 en die inligting in soortgelyke tabelle ten opsigte van die ander agt scenario's. Die parametriese waarde is die telling van elke evalueringstegniek in die nege scenario's, vir elkeen van die spesies, bymekaargetel en 'n gemiddeld is bereken. Dit is om die voorkeurspesie ten opsigte van elkeen van die evalueringstegnieke te bepaal. Die nieparametriese waarde toon die voorkeurrangorde waar 3 die mees geskikte en 1 die mins geskikte keuse voorstel. TABEL 3 toon dat boerbokboerdery volgens vier van die vyf prestasiemeting- en al drie kapitaalinvesteringsevalueringstegnieke die voorkeurboerderyspesie is. Beesboerdery is volgens een prestasiemeting- en beide die risikometingtegnieke die voorkeurboerderyspesie. Skaapboerdery is saam met bokboerdery die voorkeurspesie ten opsigte van een prestasiemetingstegniek. 


\subsubsection{Vergelyking tussen nege scenario's}

TABEL 4 is 'n opsomming van die finansiële prestasiemeting, kapitaalinvesteringsevaluerings en risiko met betrekking tot al die scenario's. Dit is die samevatting van nege tabelle soortgelyk aan TABEL 2. Die boerbokke presteer, ten opsigte van prestasiemeting, in sewe van die nege scenario's die beste. Skape is in twee van die nege scenario's die beste presteerders. Die boerbokke vaar oor die algemeen die beste in die kapitaalinvesteringsevaluerings, met die hoogste telling ook in sewe van die nege scenario's. Die skape vaar die tweede beste en behaal in twee van die sewe scenario's die hoogste telling. Skape behaal algeheel ook die hoogste telling in die 900 hektaar scenario. TABEL 4 toon verder dat beeste in al nege scenario's die laagste risiko het, gevolg deur bokke.

TABEL 4 Prestasiemeting, kapitaalinvesteringsevaluering en risiko ten opsigte van nege scenario's

\begin{tabular}{|c|c|c|c|c|c|c|}
\hline \multirow{2}{*}{$\begin{array}{l}\text { Scenario } 1 \text { tot } 9 \\
\text { Prestasiemeting }\end{array}$} & \multicolumn{3}{|c|}{ Nieparametriese } & \multicolumn{3}{|c|}{ Parametries } \\
\hline & Beeste & Skape & Bokke & Beeste & Skape & Bokke \\
\hline 1: 200 ha, R200 000 & 1 & 2 & 3 & $\star 2,68$ & $\star 3,98$ & $\star 4,85$ \\
\hline 2: 200 ha, R500 000 & 2 & 1 & 3 & 3,89 & 3,81 & 4,82 \\
\hline 3: 200 ha, R900 000 & 2 & 1 & 3 & 3,89 & 3,86 & 4,78 \\
\hline Subtotaal & 5 & 4 & 9 & 10,46 & 11,65 & 14,45 \\
\hline 4: 500 ha, R200 000 & 1 & 3 & 2 & 2,94 & 4,65 & 4,45 \\
\hline 5: 500 ha, R500 000 & 1 & 2 & 3 & 3,19 & 3,87 & 4,85 \\
\hline 6: 500 ha, R900 000 & 2 & 2 & 3 & 3,88 & 3,88 & 4,80 \\
\hline Subtotaal & 4 & 7 & 8 & 10,01 & 12,40 & 14,10 \\
\hline 7: 900 ha, R200 000 & 1 & 3 & 2 & 3,35 & 4,61 & 4,18 \\
\hline 8: 900 ha, R500 000 & 1 & 2 & 3 & 2,59 & 4,07 & 4,78 \\
\hline 9: 900 ha, R900 000 & 1 & 2 & 3 & 3,36 & 3,48 & 4,85 \\
\hline Subtotaal & 3 & 6 & 9 & 9,30 & 12,16 & 13,81 \\
\hline \multicolumn{7}{|c|}{ Kapitaalinvesteringsevaluering } \\
\hline l: 200 ha, R200 000 & 1 & 2 & 3 & $\star 0,70$ & $\star 2,32$ & $\star 2,95$ \\
\hline 2: 200 ha, R500 000 & 1 & 2 & 3 & 1,87 & 2,24 & 3,00 \\
\hline 3: 200 ha, R900 000 & 1 & 2 & 3 & 1,93 & 2,42 & 3,00 \\
\hline Subtotaal & 3 & 6 & 9 & 4,50 & 6,98 & 8,95 \\
\hline 4: 500 ha, R200 000 & 1 & 3 & 2 & 0,61 & 3,00 & 2,65 \\
\hline 5: 500 ha, R500 000 & 1 & 2 & 3 & 1,19 & 2,29 & 2,97 \\
\hline 6: 500 ha, R900 000 & 1 & 2 & 3 & 1,96 & 2,42 & 3,00 \\
\hline Subtotaal & 3 & 7 & 8 & 3,76 & 7,71 & 8,62 \\
\hline 7: 900 ha, R200 000 & 1 & 3 & 2 & $-0,23$ & 3,00 & 1,84 \\
\hline 8: 900 ha, R500 000 & 1 & 2 & 3 & 0,99 & 2,50 & 2,93 \\
\hline 9: 900 ha, R900 000 & 1 & 2 & 3 & 1,38 & 2,29 & 2,97 \\
\hline Subtotaal & 3 & 7 & 8 & 2,14 & 7,79 & 7,74 \\
\hline
\end{tabular}




\begin{tabular}{lcccccc} 
Risiko & & & & & & \\
1: 200 ha, R200 000 & 3 & 1 & 2 & $\star 2,00$ & $* 1,58$ & $\star 1,82$ \\
2: 200 ha, R500 000 & 3 & 1 & 2 & 2,00 & 1,43 & 1,75 \\
3: 200 ha, R900 000 & 3 & 1 & 2 & 2,00 & 1,43 & 1,75 \\
Subtotaal & 9 & 3 & 6 & 6,00 & 4,44 & 5,32 \\
4: 500 ha, R200 000 & 3 & 1 & 2 & 2,00 & 1,21 & 1,39 \\
5: 500 ha, R500 000 & 3 & 1 & 2 & 2,00 & 1,53 & 1,75 \\
6: 500 ha, R900 000 & 3 & 1 & 2 & 2,00 & 1,46 & 1,74 \\
Subtotaal & 9 & 3 & 6 & 6,00 & 4,20 & 4,88 \\
7: 900 ha, R200 000 & 3 & 1 & 2 & 2,00 & 0,97 & 1,17 \\
8: 900 ha, R500 000 & 3 & 1 & 2 & 2,00 & 1,48 & 1,73 \\
9: 900 ha, R900 000 & 3 & 1 & 2 & 2,00 & 1,52 & 1,73 \\
Subtotaal & 9 & 3 & 6 & 6,00 & 3,97 & 4,63 \\
\hline
\end{tabular}

Bron: Empiriese bevindings (* Totale soos volgens TABEL 2)

\section{BESPREKING EN GEVOLGTREKKINGS}

\subsection{Evalueringstegnieke}

Boerbokboerdery is volgens sewe van die tien evalueringstegnieke die voorkeurboerderyspesie, gevolg deur beesboerdery wat volgens drie tegnieke die voorkeurspesie is en skape wat saam met bokboerdery een keer die voorkeurboerderyspesie is. Vervolgens word elkeen van die tegnieke bespreek en deurgaans word die eerste en tweede voorkeurspesies uitgewys, soos aangedui in TABEL 3 .

\subsubsection{Prestasiemeting}

- Opbrengs op investering: Die investering in bokke, tesame met die investering in alle ander bates, genereer die meeste wins. Skape is in hierdie verband die tweede winsgewendste.

- Bydraepersentasie: Beeste, gevolg deur bokke, se inkomste-/uitgawe-verskil is die grootste, wat beteken vir elke rand-uitgawe genereer beeste die meeste inkomste. Anders gestel, met beesboerdery word, met betrekking tot bokke en skape, die hoogste verhouding inkomste oorgehou nadat uitgawes betaal is.

- Bate-omsetsnelheid: Skape en bokke is gelyk deurdat die benutting van totale bates met betrekking tot verkoopinkomste die hoogste is. Dit beteken dat die bates sodanig benut word dat hierdie spesies die meeste verkoopsinkomste genereer.

- Bydrae per hektaar: Bokboerdery, gevolg deur skaapboerdery, is die winsgewendste met betrekking tot elke hektaar wat beskikbaar is. 


\subsubsection{Kapitaalinvesteringsevaluering}

- Terugbetalingsperiode: Indien tydwaarde van geld geïgnoreer word, delg die netto kontant gegenereer deur skape, gevolg deur bokke, die aanvanklike kapitaalinvestering die vinnigste.

- Rekeningkundige opbrengskoers: Indien tydwaarde van geld geïgnoreer word, lewer bokke, gevolg deur skape, die hoogste gemiddelde jaarlikse wins met betrekking tot die gemiddelde waarde van die investering aan die begin en die einde van die projek.

- Netto huidige waarde: Indien alle huidige en toekomstige kontantvloei tot huidige waardes verdiskonteer word, toon die berekeninge dat bokke, gevolg deur skape, se kontantvloei die kontantuitvloei die meeste oorskry.

\subsubsection{Risiko}

- Gelykbreekpunt: Beeste se gelykbreekpersentasie is die hoogste, gevolg deur bokke. Dit beteken dat die markprys van beeste die verste kan daal alvorens geen bydrae gelewer sal word nie.

- Sensitiwiteit: Indien daar ' $n$ verlaging in markpryse is, sal beeste se relevante bydrae proporsioneel die minste verlaag, gevolg deur bokke.

Gevolgtrekking met betrekking tot evalueringstegnieke: $\varepsilon l$ keen van die evalueringstegnieke het ' $n$ ander doel en meet verskillende aspekte met betrekking tot korttermynprestasie, kapitaalinvestering en riskantheid. Al drie die tegniektipes is nodig om ' $n$ ingeligte finansiële besluit te kan neem. Bokke se prestasie is die hoogste, gevolg deur skape. Bokke se kapitaalinvesteringsevaluerings is die gunstigste, gevolg deur skape. Beeste het die laagste risiko, gevolg deur bokke.

\subsection{Nege scenario's}

Aangesien bevind is dat bokke met betrekking tot prestasiemeting (TABEL 4) in sewe van die nege scenario's en ook algeheel die hoogste puntetelling het, is die gevolgtrekking wat hieruit gemaak word, dat bokke vanuit 'n korttermynperspektief finansieel die beste van die drie spesies presteer. Daar is ook bevind dat boerbokke in sewe van die nege scenario's die hoogste puntetelling met die kapitaalinvesteringsevaluerings gekry het (TABEL 4). Skape vaar die tweede beste en behaal die hoogste telling in twee van die sewe scenario's. Hulle behaal ook algeheel die hoogste telling in die 900 hektaar scenario. Dit lei tot die gevolgtrekking dat bokke op lang termyn die beste opbrengs sal lewer en dat skape die tweede beste opbrengs sal lewer en in sekere gevalle selfs beter as bokke vaar. Beeste bied egter die laagste opbrengs op kapitaal geïnvesteer. Met betrekking tot risiko toon TABEL 4 dat beeste in al nege scenario's die hoogste puntetelling het. Bokke het die tweede meeste punte, en het ook in al die scenario's meer punte as skape behaal. Dit lei tot die gevolgtrekking dat beesboerdery die minste en boerbokboerdery die tweede minste riskant is. 
TABEL 5: Matriks van beskikbare kapitaal en beskikbare weidingsoppervlakte

\begin{tabular}{lccc}
\hline Beskikbare kapitaal & \multicolumn{2}{c}{ Beskikbare weiding } & \\
& Klein area $(200 \mathrm{ha})$ & Medium area $(500 \mathrm{ha})$ & Groot area $(900 \mathrm{ha})$ \\
\hline Min kapitaal & 1. Bokke & 1. Skape & 1. Skape \\
$($ R200 000) & 2. Skape & 2. Bokke & 2. Bokke \\
3. Beeste & 3. Beeste & 3. Beeste \\
1. Bokke & 2. Beeste & 1. Bokke & 1. Bokke \\
(R500 000) & 3. Skape & 2. Skape & 2. Skape \\
Baie kapitaal & 3. Beeste & 3. Beeste \\
$($ R900 000) & 2. Beeste & 1. Bokke & 1. Bokke \\
& 3. Skape & 2. Beeste & 2. Skape \\
\hline
\end{tabular}

Bron: Empiriese bevindings

TABEL 5 is ' $n$ samevatting van TABEL 4 wat in die vorm van ' $n$ matriks aangebied word, waar beskikbare kapitaal teenoor beskikbare weidingsoppervlakte gestel word. By die ekstreme hoeke van die matriks, groot area/min kapitaal en klein area/baie kapitaal, sal daar onderbenutting van grond en kapitaal, respektiewelik, voorkom. By die ander ekstreme hoeke van die matriks, groot area/baie kapitaal en klein area/min kapitaal, sal daar geensins onderbenutting van grond of kapitaal voorkom nie. Die puntetellings van prestasiemeting, kapitaalinvesteringsevaluering en risiko is vir elke scenario bymekaargetel. Die voorkeurrangorde (volgens hoogste telling in TABEL 4) van die drie spesies word telkens getoon. Die gevolgtrekking wat gemaak kan word, is dat indien ' $n$ klein area bewei word, bokke oor die algemeen die beste en beeste die tweede beste keuse is. Sodra ' $n$ medium grootte area bewei word, is bokke steeds die beste keuse en skape die tweede beste. Indien 'n groot grondgebied bewei word, is bokke weereens die beste keuse en skape tweede beste. Die gevolgtrekking kan ook gemaak word dat indien die beskikbare kapitaal min is, skape die beste keuse is gevolg deur bokke. Indien die beskikbare kapitaal ' $n$ medium hoeveelheid is, is bokke die beste keuse en skape tweede beste. Indien die beskikbare kapitaal baie is, is bokke die beste keuse gevolg deur beeste.

\section{SAMEVATTING EN PRAKTIESE IMPLIKASIE}

Die doel van die studie is om die vraag te beantwoord of dit finansieel lewensvatbaarder is om met boerbokke te boer in vergelyking met ander rooivleisproduserende spesies. Die somtotaal van die bestuursrekeningkundige tegnieke hou voor dat bokke oor die algemeen finansieel die beste presteer, naamlik dat bokke in sewe van die nege scenario's die hoogste telling het. Die aanbeveling is dat die gebruiker moet bepaal watter van prestasie, opbrengs op kapitaal of risiko die vernaamste is alvorens ' $n$ besluit geneem word. Vanuit die studie is die aanbeveling dat indien korttermyn finansiële prestasie en of langtermynopbrengs op kapitaal die belangrikste is, daar met boerbokke geboer moet word. Indien risiko die belangrikste oorwegingsfaktor is, moet daar met beeste geboer word. Indien die algehele finansiële analise, soos in die studie uiteengesit, beskou word, moet daar met boerbokke geboer word en tweedens 
skape. Alhoewel hierdie aanbevelings vir die spesifieke scenario's gemaak word, is die algemene aanbeveling dat elke besluitnemer sy/haar eie unieke situasie se veranderlikes behoort te gebruik en die finansiële analise te doen.

Die beperking van die studie, wat ontstaan het aangesien ' $n$ aantal aannames gemaak word, is soos volg:

- Die resultate van die ondersoek is slegs geldig vir Potchefstroom en die naby-omliggende gebied en die drakrag, gebaseer op die gebied se gemiddeld, kan selfs in die gebied verskil.

- Dosering is gegrond op die behoeftes aan die omgewing soos in Januarie 2011.

- Aankoop- en verkooppryse is op Januarie 2011 gebaseer.

- Die insetkoste van veehanteringsgeriewe kan verskil soos wat boerderypraktyke en benaderings verskil.

- Die fisiese vorm van die plaas kan 'n direkte invloed op die omheiningskoste hê.

- Lam- en kalfpersentasie kan verskil soos praktyke en benaderings van verskillende boere verskil;

- Die kombinasie van aanvangskapitaal en plaasgrootte kan 'n invloed op die resultate hê.

- Berekeninge is slegs op 'n vyfjaarperiode gebaseer.

As gevolg van hierdie beperkings (aannames) is dit baie riskant om te veralgemeen, maar die praktiese waarde van die studie is daarin opgesluit dat die Microsoft Excel program wat vir berekeninge in hierdie studie gebruik is, ook aan die leser beskikbaar gestel word deur die volgende webadres: http://sites.google.com/site/rooivleisvergelyking/. Dus kan veranderlikes, soos plaasgrootte, kapitaal beskikbaar, drakrag, koste en pryse na gelang van elke unieke scenario verander word, en die resultate daarvolgens bereken word. Die resultate van die studie vergemaklik die besluitneming rakende die keuse tussen die tipe rooivleisbedryf vir verskillende unieke scenario's vergemaklik, want elke grondgebruiker kan hiermee bepaal watter spesie volgens die verskillende bestuursrekeningkundige evalueringstegnieke aanbeveel word.

Die belangrikheid van die studie is dat dit die eerste poging is om die lewensvatbaarheid van drie rooivleisproduserende spesies deur middel van ' $n$ gevallestudie met verskillende scenario's met mekaar te vergelyk. Verdere navorsing behoort in die volgende verband gedoen te word:

- Die aantal evalueringstegnieke kan uitgebrei word om meer substansie aan die resultate te gee.

- In aansluiting hierby kan die aantal spesies in die vergelykings ook uitgebrei word.

- 'n Ontleding van die gedrag van koste tussen die verskillende scenario's kan gedoen word.

- Die optimale kombinasie van plaasgrootte en beskikbare kapitaal ten opsigte van elke spesie kan bepaal word. 


\section{BRONNELYS}

Acocks, J.P.H. (1988). Veld types of South Africa. In Botanical Research Institute: Memoirs of the Botanical Survey of South Africa. Pretoria (pp.1-146).

Boshoff, J. (2011). Mondelinge kommunikasie met outeur op 8 Februarie. Potchefstroom.

Botha, T. (1999). Boerbokke het wêreld aan die gons. Landbouweekb/ad: 10 September, pp.10-12.

Cameron, M.R., Luo, J., Sahlu, T., Hart, S.P., Coleman, S. W. \& Goetch, A. L. (2001). Growth and slaughter traits of Boer $x$ Spanish, Boer x Angora, and Spanish goats consuming a concentrate-based diet. Journal of Animal Science, 79(6), pp. 1423-1430.

Casey, N.H. \& Van Niekerk, W.A. (1988). The Boer Goat (Part 1): Origin, adaptability, performance testing, reproduction and milk production. Small Ruminant Research, 1(3), pp. 291-302.

Casey, N. H. (1992). Goat meat in human nutrition. In Indian Council of Agricultural Research. Proceedings of the Fifth International Conference on goats. New Delhi. Vol. 2, Part II, pp. 582-596.

Cilliers, J. (2011). Mondelinge kommunikasie met outeur op 17 Maart. Potchefstroom.

Correia, C., Flynn, D., Uliana, E. \& Wormald, M. (2010). Financial management, $7^{\text {th }}$ edition. Cape Town: Juta.

De Chalain, F. (2010). Mondelinge kommunikasie met outeur op 10 Julie. Potchefstroom.

De Waal, J-M. (2006). Bok-plan teen armoede. Landbouweekblad, 25 Augustus, p. 14.

Du Plessis, I., Van Der Waal, C. \& Webb, E.C. (2004). A comparison of plant form and browsing height selection of four small stock breeds - Preliminary results. South African Journal of Animal Science, 34, pp. 31-32.

Ferreira, A.V. (2004). Essential amino acid requirements of meat and milk goats. African Journal of Animal Science, 34, pp. 46-47.

Flyvbjerg, B. (2006). Five misunderstandings about case-study research. Qualitative Inquiry, 12(2), pp. 219-245.

Gadiyaram, K.M. \& Kannan, G. (2004). Comparison of textural properties of low-fat chevon, beef, pork, and mixed-meat sausages. South African Journal of Animal Science, 34(1), p. 168.

Gouws, A. (2002). Boerbok kan man staan: Wêreld soek ons boerbokke. Landbouweekblad, 3 Mei, pp. 12-15.

Haschick, S.L. \& Kerley, G.I.H. (1997). Browse intake rates by bushbuck and boergoats. East African Wildlife Society Journal, 35, pp. 146-155.

Hawawini, G. \& Viallet, C. (2011). Finance for executives: Managing for value creation, $4^{\text {th }}$ edition. Boston: South-Western College Publishers.

Landbouweekblad. (2011). [Intyds] Beskikbaar:. http://www.landbou.com/. (8 Februarie 2011). Landbouweekblad. (2013). [Intyds] Beskikbaar: Webwerf. http://www.landbou.com/. (15 Junie 2013).

Lovemore, F.C.H. \& Brümmer, L.M. (2011). The ABC of financial management, $2^{\text {nd }}$ edition. Pretoria: Van Schaik. 
Lochner, H. (2002). Boerbok het belangrike rol in diereproduksie. Landbouweekblad, 11 Oktober, pp. $52-53$.

Mason, I.L. (1988). World Dictionary of Livestock Breeds, $3^{\text {rd }}$ edition. Wallingford: C.A.B International.

Malan, S.W. (2000). The improved Boer goat. Small Ruminant Research, 36 (2), pp. 165-170.

Midgley, D. (2007). Meer parings sorg vir dividend. In Pfizer Animal Health Publications. [Intyds] Beskikbaar: http://www.pfizer.co.za/RunTime/POPContentRun.aspx?pageidref=1975. (8 Oktober 2009).

Mouton, J. (2011). Mondelinge kommunikasie met outeur op 4 Februarie. Potchefstroom.

Nell, W.T. \& Napier, J.R. (2005). Strategic approach to farming success. Proceedings of the $15^{\text {th }}$ International Farm Management Congress of Food Safety and Sustainability, August, Campinas. [Intyds] Beskikbaar: http://www.ifmaonline.org/pdf/congress/05Nell\%20Napier.pdf. (10 Januarie 2010).

Naude, F. (2011). Mondelinge kommunikasie met outeur op 8 Februarie. Potchefstroom.

Omphile, U.J., Aganga, A.A., Thsireletso, K. \& Nkele, R. (2004). Foraging strategies of sheep and goats under semi-intensive management in Botswana. South African Journal of Animal Science, 34, pp. 120-121.

SA Boerboktelersvereniging. (2011). Webwerf. [Intyds] Beskikbaar: http://www.boerboksa.co.za/. (9 September 2011).

Sheridan, R., Ferreira, A.V. \& Hoffman, L.C. (2003). Production efficiency of South African Mutton Merino lambs and Boer Goat kids receiving either a low or a high energy feedlot diet. Small Ruminant Research, 50(1), pp. 75-82.

Stake, R.E. (1995). The art of case study research. London: SAGE.

Statistics South Africa, 2006. Survey of Large Scale Agriculture. [Intyds] Beskikbaar: http://www.statssa.gov.za/PublicationsHTML/P110112006/html/P110112006_l.html?glnitialPosX=1 0px\&gInitialPosy=10px\&gZoomValue=100. (3 Augustus 2011).

Steyn, A.G.W., Smit, C.F., Du Toit, S.H.C. \& Strasheim, C. (1999). Moderne statistiek vir die praktyk, $5^{\text {de }}$ uitgawe. Pretoria: Van Schaik.

Van Zyl, A. (2011). Mondelinge kommunikasie met outeur op 7 Februarie. Potchefstroom.

Van Zyl, B. (2011). Mondelinge kommunikasie met outeur op 7 Februarie. Potchefstroom. 